\title{
Molecular-genetic diversity of the ascomycetous yeast genus Arthroascus: Arthroascus babjevae sp. nov., Arthroascus fermentans var. arxii var. nov. and geographical populations of Arthroascus schoenii
}

Correspondence

Gennadi I. Naumov gnaumov@yahoo.com

\author{
Gennadi I. Naumov, ${ }^{1}$ Elena S. Naumova, ${ }^{1}$ Maudy Th. Smith ${ }^{2}$ \\ and G. Sybren de Hoog ${ }^{2}$ \\ ${ }^{1}$ State Institute for Genetics and Selection of Industrial Micro-organisms, Moscow 117545, \\ Russia \\ ${ }^{2}$ Centraalbureau voor Schimmelcultures, 3584 CT Utrecht, The Netherlands
}

\section{INTRODUCTION}

The biological species concept, initially introduced for higher eukaryotes, has been successfully applied to some yeast genera, including Metschnikowia (Pitt \& Miller, 1970; Lachance \& Bowles, 2002, 2004), Saccharomyces (Naumov, 1996; Naumov et al., 2000), Kluyveromyces (Naumov \& Naumova, 2002; Naumova et al., 2004), Williopsis and Zygowilliopsis (Naumov, 1987). Also, the genus Arthroascus is genetically well defined, as it includes closely related species that share a common mating type system (Naumov et al., 1985). These predatory yeasts are able to penetrate cells

\footnotetext{
Abbreviation: ITS, internal transcribed spacer.

The GenBank/EMBL/DDBJ accession numbers for the D1/D2 and ITS sequences obtained in this study are detailed in Table 1.

Results of genetic analysis between three $A$. fermentans strains and ex-type cultures of $A$. javanensis and $A$. schoenii, results of genetic analysis of intrastrain and intrapopulation hybrids of $A$. schoenii strains and DNA-DNA reassociation results between Arthroascus strains are available as supplementary material in IJSEM Online.
}

of ascomycetous and basidiomycetous yeasts and kill them by digesting the cell content (Kreger-van Rij \& Veenhuis, 1973; Lachance, 1995; Lachance et al., 2000). The biological aspects of this phenomenon are of great interest, in particular for biological control studies (Pimenta et al., 2004).

The genus Arthroascus was proposed by von Arx (1972) for a single species, Arthroascus javanensis. Initially, this yeast was known as Endomyces javanensis, and it was later assigned to the genus Endomycopsis (Stelling-Dekker, 1931; Lodder \& Kreger-van Rij, 1952; Kreger-van Rij, 1970). The second species, Arthroascus schoenii, was initially also introduced as a member of the genus Endomyces, by Nadson \& Krassilnikov (1932). Genetic hybridization established the affiliation of A. schoenii to Arthroascus (Naumov et al., 1985; Bab'eva et al., 1986), which was later confirmed using DNADNA reassociation (Smith et al., 1990) and rDNA sequencing (Naumov et al., 2003). More recently, three strains isolated from soil in Taiwan were assigned to the genus Arthroascus on the basis of morphological and physiological properties (Lee et al., 1994); based on DNA-DNA 
reassociation data, the species Arthroascus fermentans was described.

Kurtzman \& Robnett (1995), using sequence data of the D1/D2 domain of the large subunit (26S) rDNA, considered Arthroascus to be congeneric with the genus Saccharomycopsis. The latter genus also contains predatory yeasts. Kurtzman \& Robnett (1998) and Kurtzman \& Smith (1998) followed this classification. Recently, the relatedness of 16 species assigned to the Saccharomycopsis clade has been reconsidered on the basis of molecular and genetic data, resulting in the reinstatement of the genus Arthroascus (Naumov et al., 2003). Phylogenetic analysis of the D1/D2 rDNA region showed that the Saccharomycopsis clade is not monophyletic and apparently consists of a complex of separate genera, one of which is Arthroascus. The species A. javanensis, A. schoenii and A. fermentans have the same system of mating types responsible for their crossing and form a distinct lineage (bootstrap value, $100 \%$ ) with low phylogenetic affinity to other members of the Saccharomycopsis clade. The Arthroascus species can be well distinguished from the remaining taxa in the clade by the perforation of hyphal septa: cross walls with a closure line, i.e. the remnants of plasmalemma after centripetal closure during development of the wall (Kreger-van Rij, 1984a, b). The morphological peculiarity of forming ascospores with a ledge within swollen hyphal cells unites the genetically related species A. javanensis, A. schoenii and A. fermentans.

In the present paper, we examine Arthroascus strains of different origins. Comparative studies using PCR fingerprinting reveal four endemic populations within the species A. schoenii: European, North American, Far-East Asian and Hawaiian. On the basis of genetic hybridization, DNA-DNA reassociation studies and sequencing of the D1/D2 domain of $26 \mathrm{~S}$ rDNA and the internal transcribed spacers ITS1 and ITS2, two novel taxa are reported: Arthroascus babjevae sp. nov. and Arthroascus fermentans var. arxii var. nov. In addition, A. fermentans is redefined on the basis of genetic criteria.

\section{METHODS}

Yeast strains, culture conditions and genetic hybridization. The strains used and their origins are listed in Table 1. Yeast cells were grown at $28^{\circ} \mathrm{C}$ on YPD complete medium containing $\left(1^{-1}\right)$ : glucose, $20 \mathrm{~g}$; peptone, $10 \mathrm{~g}$; yeast extract, $10 \mathrm{~g}$; agar, $20 \mathrm{~g}$. The minimal medium contained $\left(1^{-1}\right)$ : yeast nitrogen base without amino acids (Difco), 6.7 g; glucose, $20 \mathrm{~g}$; agar, $20 \mathrm{~g}$. Because all strains of Arthroascus studied in this work had natural methionine auxotrophy, methionine was added to the minimal nutritional medium. Spore formation was induced by cell incubation for 1-2 days on a culture medium containing $\left(1^{-1}\right)$ : maltose, $30 \mathrm{~g}$; agar, $20 \mathrm{~g}$. Auxotrophic mutations were induced in haploid cells by UV light on a complete agar medium. To obtain hybrids, mass crossing of haploid cells marked with complementary auxotrophic mutations on the sporulation medium was performed. After 1 day of incubation, the resulting mixture of two strains was lawn-plated on the minimal medium. After 3 days of incubation, prototrophic hybrid colonies were additionally cloned on the minimal medium and then transferred to YPD medium. After 1 day of incubation, the colonies were transferred to the sporulation medium. Sporulation of hybrids was monitored at all stages of plating. Spores were isolated using a micromanipulator. Ascus walls were preliminarily destroyed using the stomach juice of the garden snail Helix pomatia. In addition to tetrad analysis, random spore analysis was done using diethyl ether treatment of sporulating cultures (Dawes \& Hardie, 1974).

Phenotypic characterization. Fermentation ability and utilization of carbon and nitrogen compounds were tested according to the methods described by Yarrow (1998).

DNA extraction and PCR fingerprinting. DNA extraction was done as described previously (Naumov et al., 1997a). The primers used included (GTG) $)_{5}$ and M13 core sequence (5'-GAGGGTGGCGGTTCT-3'). PCR amplification was performed using an MJ Research PTC-100 Programmable Thermal Controller in a total volume of $25 \mu$ containing $1 \times$ PCR buffer, $2 \mathrm{mM} \mathrm{MgCl}_{2}, 2 \mathrm{U}$ Taq polymerase, $0 \cdot 2 \mathrm{mM}$ each $\mathrm{dNTP}, 30 \mathrm{pmol}$ primer and $25 \mathrm{ng}$ genomic template DNA. The thermal cycler was programmed for 35 cycles of $1 \mathrm{~min}$ at $94^{\circ} \mathrm{C}, 1 \mathrm{~min}$ at $55^{\circ} \mathrm{C}$ and $2 \mathrm{~min}$ at $72^{\circ} \mathrm{C}$ and a final extension of $10 \mathrm{~min}$ at $72^{\circ} \mathrm{C}$. PCR products were analysed by electrophoresis in $1.2 \%$ agarose gels. Gels were stained with ethidium bromide and photographed under UV light.

For the analysis of fingerprints, the amplified bands for each strain and two primers (separately) were encoded as ' 0 ' (band absent) and ' 1 ' (band present). The binary matrices were combined to form a composite fingerprint for each strain and were then converted into simple matching coefficient data $\left[S_{\mathrm{SM}}=(a+d) / n ; a=\right.$ both characters are ' 1 ', $d=$ both characters are ' 0 ', $n=$ number of characters]. Corresponding distance values $\left(D=1-S_{\mathrm{SM}}\right)$ for each strain were finally used to construct a dendrogram by implementing the neighbour-joining (NJ) method from the TREECON package (Van de Peer \& De Wachter, 1994).

Isolation of DNA, G+C content determinations and DNADNA complementarities. Isolation of nuclear DNA, $\mathrm{G}+\mathrm{C}$ content calculations and determinations of DNA-DNA relatedness were performed as described previously (Smith et al., 1995).

DNA sequencing analysis of the D1/D2 domain of 26S rDNA and the internal transcribed spacer (ITS) region. The divergent D1/D2 domain at the $5^{\prime}$ end of the 26S rRNA gene was amplified with the primers NL-1 and NL-4 as described by Kurtzman \& Robnett (1997).

The entire ITS region, including ITS1, ITS2 and the intervening $5 \cdot 8 \mathrm{~S}$ rRNA gene, was amplified using primers V9D and LS266 as described previously (Gerrits van den Ende \& de Hoog, 1999). The amplified DNAs were purified using GFX columns (Amersham Pharmacia Biotech) according to the manufacturer's instructions. Direct sequencing of both strands of the D1/D2 and ITS regions was performed using capillary electrophoresis on an ABI Prism 3700 automated DNA sequencer (PE Biosystems). The nucleotide sequences determined for Arthroascus strains have been deposited in GenBank (see Table 1 for details). Existing sequences for the type cultures of Arthroascus species and other members of the Saccharomycopsis clade (Kurtzman \& Robnett, 1995; Kurtzman, 1999; Lachance et al., 2000) were retrieved from GenBank.

Alignment and phylogenetic analysis. Sequences were edited and assembled by using the SeqMan package (DNAStar Inc.). A preliminary automatic alignment was generated using BioNumerics version 1.50 (Applied Maths) and adjusted manually. The TREECON package was used to generate an NJ tree using Kimura's twoparameter correction. A total of 100 bootstrap replicates were used for analysis. The topology was verified using several algorithms (parsimony, Ward's averaging, UPGMA). 


\section{RESULTS AND DISCUSSION}

In this study, we compared 28 Arthroascus strains isolated from widely different geographical localities in Europe, FarEast Asia, Indonesia, North America and Hawaii (Table 1) in order to assess the genetic diversity of the yeasts. Most of the strains studied were originally designated as Arthroascus (Saccharomycopsis) javanensis. In our approach, we combined genetic hybridization analysis with various molecular methods: PCR fingerprinting, DNA-DNA reassociation and sequencing of variable rDNA regions.

\section{The biological species $A$. fermentans}

The results of the genetic circumscription of the biological species A. fermentans are presented in Supplementary Table S1 in IJSEM Online. Strains CBS 7830, CBS 7831 and CBS 7832 showed high ascospore viability of 89,89 and $100 \%$, respectively. Their monosporic cultures carrying various auxotrophic mutations were used for intra- and interspecies crosses. High ascospore viability of intrastrain and interstrain hybrids and normal digenic segregation of control auxotrophic markers confirmed the assignment of strains CBS 7830, CBS 7831 and CBS 7832 to a single biological species $A$. fermentans. Intraspecies hybrids of A. schoenii and A. javanensis were also fertile. In contrast, interspecies crosses between A. fermentans, A. schoenii and $A$. javanensis yielded sterile hybrids with ascospore viabilities of $0-3 \%$. Thus, A. fermentans, A. schoenii and A. javanensis represent reproductively isolated genetic populations. According to the biological species concept as applied to higher eukaryotes, these entities should be viewed as separate species.

\section{Geographical populations of $\boldsymbol{A}$. schoenii}

PCR fingerprinting. Initially, all strains studied were characterized by PCR fingerprinting using two primers, $(\mathrm{GTG})_{5}$ and M13. Microsatellite primer $(\mathrm{GTG})_{5}$ generated complex banding patterns in the strains studied. The type cultures of A. schoenii (CBS $7223^{\mathrm{T}}$ ), A. javanensis (CBS $2555^{\mathrm{T}}$ ) and A. fermentans (CBS $7830^{\mathrm{T}}$ ) displayed clearly distinct profiles (Fig. 1, lanes 1, 23 and 24, respectively). Sixteen isolates originally designated as A. javanensis produced PCR fingerprints very similar to those of six $A$. schoenii strains, including the type culture CBS $7223^{\mathrm{T}}$ (Fig. 1, lanes 1-22). Three A. fermentans strains showed mutually identical profiles (Fig. 1, lanes 24-26). Within the A. schoenii profile type, some polymorphisms were observed. For example, two major bands of about $400 \mathrm{bp}$ were seen in all four European strains (Fig. 1, lanes 1-4). PCR profiles of Hawaiian isolates were also slightly different from the others (Fig. 1, lanes 19-22). Similar results were obtained with primer M13 (not shown).

Combined cluster analysis of the fingerprints generated by primers $(\mathrm{GTG})_{5}$ and M13 is presented in Fig. 2 . The 22 A. schoenii strains formed a separate cluster, which can be further subdivided into four groups corresponding to four geographical populations: European, North American,
Hawaiian and Far-East Asian. The only exception was North American isolate UCD 52-317.54, which was found between two Far-East-Asian strains (Fig. 2). Thus, the cluster analysis revealed a correlation between the fingerprints and geographical origin of $A$. schoenii strains.

Genetic hybridization of $\boldsymbol{A}$. schoenii isolates. Representative strains from four geographical populations were subjected to genetic hybridization analysis. First, fertile monosporic lines were obtained from all strains, except non-sporulating strain UCD 71-182, in which we isolated only a monocellular clone. The strains cloned were marked by various auxotrophic mutations. Hybrids were formed in all crossing combinations. Each hybrid was analysed for fertility and segregation of control markers. Intrastrain and intrapopulation hybrids were highly fertile (73-96\% ascospore viability) with regular digenic segregation of control markers. Fertility of interpopulation hybrids was slightly lower: 51-89\%. Nevertheless, the latter hybrids showed normal meiotic segregation of control markers (for details see Supplementary Table S2 in IJSEM Online).

We performed a series of DNA-DNA reassociation experiments (see Supplementary Fig. S1 in IJSEM Online). High reassociation values of $89-100 \%$ were observed between $A$. schoenii strains isolated in Europe, Far-East Asia and North America. These results agree well with the data obtained by genetic hybridization analysis (see Supplementary Table S2 in IJSEM Online). Both approaches confirmed the conclusion based on the PCR fingerprinting that the strains studied belonged to the same biological species, A. schoenii. Judging from the high percentages of fertility of the interpopulation hybrids and high reassociation values, there is no significant divergence between the $A$. schoenii populations inhabiting Europe, Far-East Asia, North America and the Hawaiian islands. Unlike A. schoenii, geographical populations of Kluyveromyces lactis and Saccharomyces paradoxus yield semi-fertile hybrids and, therefore, are partly reproductively isolated (Naumov \& Naumova, 2002; Naumov et al., 1993, 1997b, 1998). Our results show that the species A. schoenii has a worldwide distribution: strains collected in different regions of the world are homogeneous from a classical genetic point of view. In this respect, it is similar to another cosmopolitan, panmictic yeast, Saccharomyces cerevisiae. Populations of the latter species from different geographical and ecological origins produce highly fertile hybrids with regular segregation of control markers (Naumov et al., 1993, 1998; Liti et al., 2005). A. javanensis is a separate species and is represented only by the type culture, CBS $2555^{\mathrm{T}}$, isolated from Java in Indonesia.

\section{Determination of taxonomic status of two Arthroascus strains having specific PCR fingerprints}

Among the 28 Arthroascus strains studied, two Japanese isolates, IFO 10138 and UCD 67-278, displayed peculiar patterns with primers (GTG) 5 and M13 (Fig. 1, lanes 27 and 28 , respectively). Based on the fingerprints, the two strains 
Table 1. Arthroascus strains studied

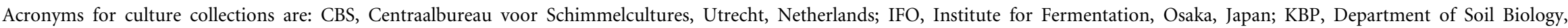

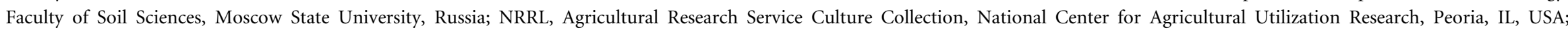

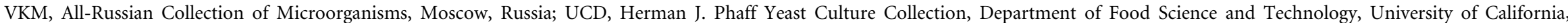

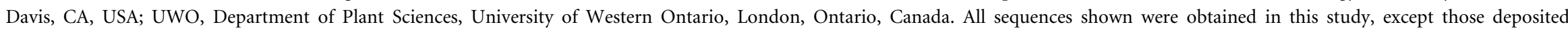
under accession numbers U40107, U40126 and U73600. T, Ex-type culture.

\begin{tabular}{|c|c|c|c|c|c|}
\hline \multirow[t]{2}{*}{ Strain } & \multirow[t]{2}{*}{ Other designation } & \multirow[t]{2}{*}{ Source of isolation } & \multirow[t]{2}{*}{ Reference or isolator } & \multicolumn{2}{|c|}{ GenBank accession no. } \\
\hline & & & & D1/D2 & ITS \\
\hline \multicolumn{6}{|l|}{ A. javanensis } \\
\hline CBS $2555^{\mathrm{T}}$ & VKM Y-1069 & Soil, Java, Indonesia & Klöcker (1909) & U40107 & DQ361058 \\
\hline \multicolumn{6}{|l|}{ A. fermentans } \\
\hline CBS $7830^{\mathrm{T}}$ & NRRL Y-17710 ${ }^{\mathrm{T}}$ & Soil of orchards, Taiwan & Lee et al. (1994) & U73600 & DQ361059 \\
\hline CBS 7831 & NRRL Y-17711 & Soil of orchards, Taiwan & Lee et al. (1994) & & \\
\hline CBS 7832 & NRRL Y-17712 & Soil of orchards, Taiwan & Lee et al. (1994) & & \\
\hline \multicolumn{6}{|l|}{ A. schoenii } \\
\hline CBS $7223^{\mathrm{T}}$ & VKM Y-1073 & Exudate of Quercus robur, Kaluga, Russia & N. A. Krassilnikov & U40126 & DQ361045 \\
\hline CBS 7048 & KBP 2695 & Exudate of Q. robur, Moscow district, Russia & Bab'eva et al. (1986) & & DQ361046 \\
\hline CBS 10273 & KBP 3099 & Pachyiulus flavipes, Yalta, Crimea, Ukraine & V. N. Thanh & & \\
\hline CBS 7425 & & Panagrellus zymosiphilus, Italy & C. Schann & AY165962 & DQ361047 \\
\hline CBS $6423^{*}$ & & Soybean-protein factory, Japan & Nakase (1971) & AY165964 & DQ361051 \\
\hline CBS 6449 & & Rotten tree trunk, Japan & K. Kodama & AY165963 & DQ361057 \\
\hline CBS 9154 & UCD 52-317.54 & Exudate of Quercus kelloggii, California, USA & Phaff \& Knapp (1956) & & DQ361056 \\
\hline CBS 9155 & UCD 71-182 & Flux of Myoporum sandwicense, Ahumoa, HI, USA & H. J. Phaff & AY165961 & DQ361050 \\
\hline CBS 9156 & UCD $72-139$ & Flux of $M$. sandwicense, Ahumoa, HI, USA & H. J. Phaff & AY165960 & \\
\hline CBS 9157 & UCD $72-142$ & Flux of M. sandwicense, Ahumoa, HI, USA & H. J. Phaff & & DQ361048 \\
\hline CBS 9158 & UCD 72-156 & Flux of M. sandwicense, Ahumoa, HI, USA & H. J. Phaff & & DQ361049 \\
\hline CBS 9159 & UWO (PS) 80-91 & Quercus rubra, Ontario, Canada & Bowles \& Lachance (1983) & AY165958 & DQ361053 \\
\hline CBS 9160 & UWO (PS) 80-92 & Q. rubra, Ontario, Canada & Bowles \& Lachance (1983) & & \\
\hline CBS 9161 & UWO (PS) 80-93 & Q. rubra, Ontario, Canada & Bowles \& Lachance (1983) & & \\
\hline CBS 9162 & UWO (PS) 91-123.2 & Quercus alba, Ontario, Canada & M.-A. Lachance & & \\
\hline CBS 9163 & UWO (PS) 91-125.1 & Q. rubra, Ontario, Canada & M.-A. Lachance & & DQ361055 \\
\hline CBS 9164 & UWO (PS) 92-247.1 & Drosophila sp., tequila factory, Mexico & Lachance (1995) & AY165959 & DQ361052 \\
\hline CBS 9165 & UWO (PS) 99-507.6 & Q. rubra, Ontario, Canada & M.-A. Lachance & & \\
\hline CBS 9166 & UWO (PS) 99-531.3 & Q. rubra, Ontario, Canada & M.-A. Lachance & & DQ361054 \\
\hline NRRL YB-1542 & & Soil in apple orchard, Peoria, IL, USA & & & \\
\hline NRRL YB-2401 & & Rotten apple, Carbondale, IL, USA & & & \\
\hline NRRL YB-2404 & & Rotten apple, Carbondale, IL, USA & & & \\
\hline \multicolumn{6}{|l|}{ A. babjevae } \\
\hline CBS $9167^{\mathrm{T}}$ & UCD $67-278^{\mathrm{T}}$ & Quercus acutissima, Kawaminami, Japan & Phaff et al. (1972) & DQ361062 & DQ361061 \\
\hline \multicolumn{6}{|l|}{ A. fermentans var. arxii } \\
\hline CBS $9168^{\mathrm{T}}$ & IFO $10138^{\mathrm{T}}$ & Flower of Tricyrtis flava, Miyazaki, Japan & Mikata (1985) & DQ361063 & DQ361060 \\
\hline
\end{tabular}

G *Ex-type culture of Pichia nonfermentans Nakase. 


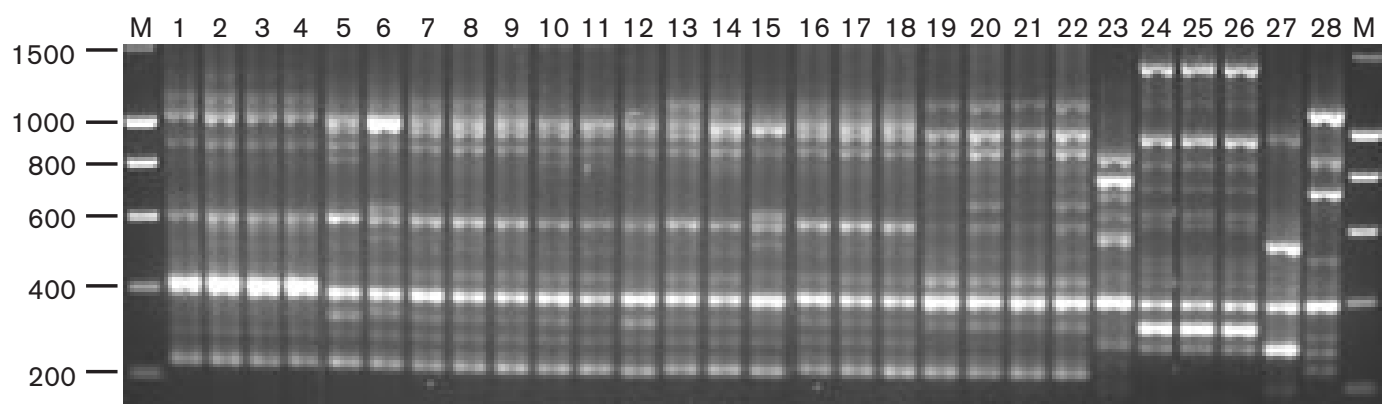

Fig. 1. PCR fingerprints of Arthroascus strains generated with the microsatellite primer (GTG) $)_{5}$. Lanes: 1-22, A. schoenii strains CBS 7223 (1), CBS 7048 (2), CBS 7425 (3), KBP 3099 (4), CBS 6423 (5), CBS 6449 (6), UWO 80-91 (7), UWO 80-92 (8), UWO 80-93 (9), UWO 91-123.2 (10), UWO 91-125.1 (11), UWO 92-247.1 (12), UWO 99-507.6 (13), UWO 99-531.3 (14), UCD 52-317.54 (15), NRRL YB-1542 (16), NRRL YB-2401 (17), NRRL YB-2404 (18), UCD 71-182 (19), UCD 72-139 (20), UCD 72-142 (21) and UCD 72-156 (22); 23, A. javanensis CBS 2555; 24-26, A. fermentans strains CBS 7830 (24), CBS 7831 (25) and CBS 7832 (26); 27, Arthroascus sp. IFO 10138; 28, Arthroascus sp. UCD 67-278. Lanes M, Molecular size marker (SmartLadder; Eurogentec); sizes are indicated in base pairs.

could not be assigned to any of the known Arthroascus species. To elucidate their taxonomic status, we used sequence analysis of the D1/D2 and ITS regions of rDNA, genetic hybridization analysis and DNA-DNA reassociation.

The D1/D2 nucleotide sequences obtained for strains IFO 10138 and UCD 67-278 were aligned with the corresponding sequences of A. schoenii, A. fermentans and A. javanensis, as well as 13 other species currently included in the Saccharomycopsis clade. Fig. 3 shows the phylogenetic relationship between these strains and other members of the genus Arthroascus. The Arthroascus strains showed close relatedness to one another and formed a well-separated cluster (bootstrap value, $100 \%$ ) within the Saccharomycopsis clade. The cluster could be subdivided into four groups. The first group included A. schoenii strains from different geographical populations. They had identical D1/D2 sequences, except for the Hawaiian isolates, which exhibited two base differences. The second group consisted of the type culture of A. javanensis. Strain IFO 10138 and the type culture of A. fermentans, having identical D1/D2 sequences, formed the third group. The fourth group comprised strain UCD 67-278 only. Comparative sequence analysis revealed that the latter strain differed by 7,11 and 22 bases, respectively, from the type cultures of $A$. schoenii, A. javanensis and A. fermentans. These results suggest that it belongs to an undescribed species of the genus Arthroascus. Close $18 \mathrm{~S}$ rDNA relatedness of IFO 10138 and the type culture of A. fermentans can be seen from the published data (Yamada et al., 1998). However, the latter authors incorrectly assigned the strain to A. javanensis.

Seventeen Arthroascus strains were further compared in the ITS region and found to be separated into five lineages:

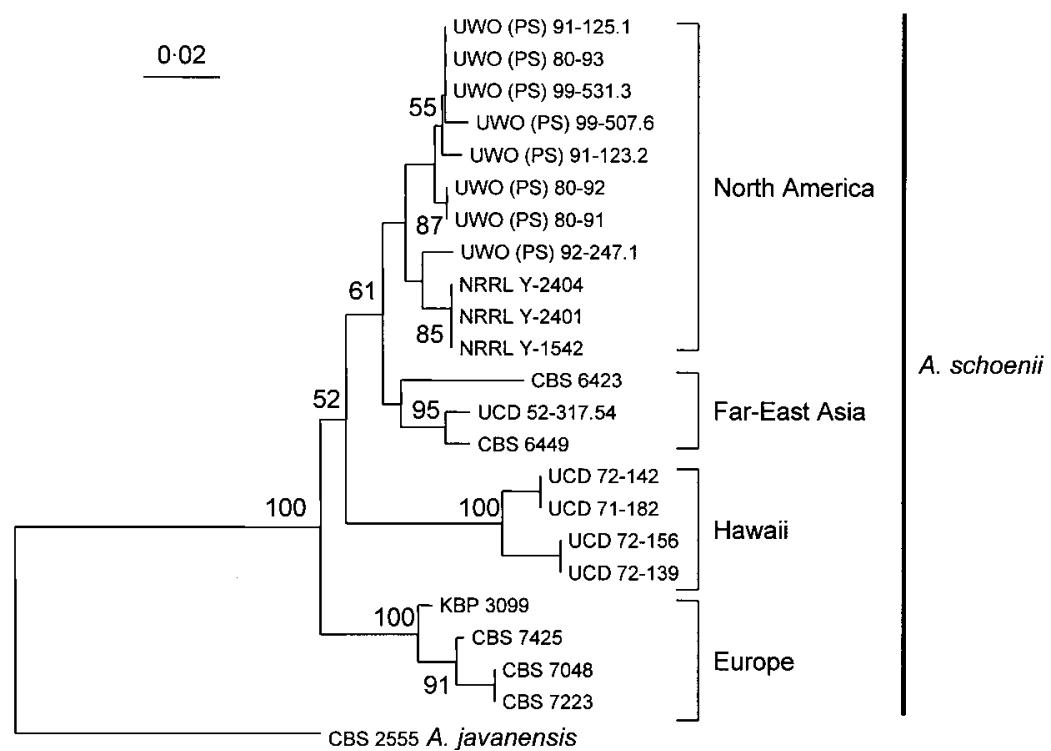

Fig. 2. Neighbour-joining tree showing differentiation of $A$. schoenii strains based on combining the fingerprints obtained with primers $(\mathrm{GTG})_{5}$ and M13. Bar, dissimilarity of 0.02 (corresponding to the fraction of average fragment differences between PCR fingerprints). 


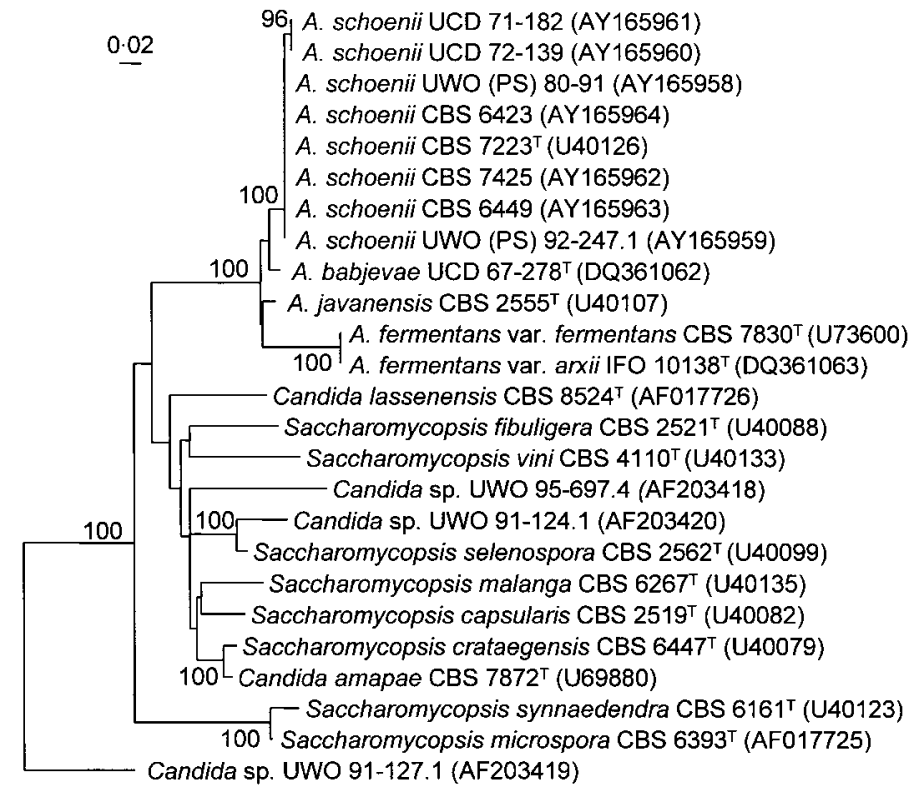

Fig. 3. Neighbour-joining tree showing phylogenetic relationships between the 16 species within the Saccharomycopsis clade based on large subunit D1/D2 rDNA sequences. Bootstrap values from 100 replications are shown (only values $>90$ are indicated). Bar, 20 estimated base substitutions per 1000 nucleotide positions. T, Ex-type culture.
A. schoenii strains, UCD 67-278, the type culture of $A$. fermentans, IFO 10138 and the type culture of $A$. javanensis (data not shown). The differences between A. schoenii strains from four geographical locations did not exceed 4 base substitutions. The ITS sequence analysis showed that IFO 10138 can be differentiated from the type culture of $A$. fermentans on the basis of 11 base substitutions. The ITS region of UCD 67-278 differed by more than 30 base substitutions.

Strains IFO 10138 and UCD 67-278 were crossed with one another and with the type cultures of A. schoenii, A. javanensis and A. fermentans. Homothallic strain IFO 10138 sporulated well and showed $97 \%$ ascospore viability. Strain UCD 67-278 had lower sporulation. The monosporic culture of IFO 10138 and the single-cell clone of UCD 67-278 were marked with auxotrophic mutations. Intrastrain crosses of both strains showed high ascospore viability (100 and $83 \%$, respectively) and regular digenic segregation of control markers (Tables 2 and 3, hybrids number 46, 58 and 59). IFO 10138 and UCD 67-278 yielded hybrids with each other and with all type cultures of described Arthroascus species, confirming their assignment to the same genus. The resulting hybrids were analysed for ascospore viability and recombination of control auxotrophic markers. Strain IFO 10138 formed almost sterile hybrids with the type cultures of A. javanensis and A. schoenii (Table 2, hybrids number 47-54). Most of the surviving ascospores of hybrids number 47-54 were prototrophic and did not carry parental auxotrophic markers. This suggests that they are not the products of meiotic division: such spores apparently represent hybrid heterozygotic diploids. Hybrids between IFO 10138 and A. fermentans showed low ascospore viability of $6-31 \%$. Although the majority of surviving segregants were prototrophic, there were also double auxotrophic recombinants $(a b)$, indicating a possibility of genetic exchange between strain IFO 10138 and A. fermentans (Table 2, hybrids number 55-57). On the other hand, strain UCD 67278 formed sterile hybrids with IFO 10138 and with the type cultures of A. schoenii, A. javanensis and A. fermentans (Table 3, hybrids number 60-68). Random spore analysis of the hybrids revealed some surviving ascospores, which were characterized by irregular meiotic segregation of control auxotrophic markers with predominance of prototrophic segregants and auxotrophic markers of only one parental type. The absence of double auxotrophic recombinants $(\mathrm{ab})$ in the progeny of the hybrids indicates that strain UCD 67-278 is genetically isolated from IFO 10138 and the type cultures of A. schoenii, A. javanensis and A. fermentans and, therefore, does not belong to any of these species.

IFO 10138 showed an intermediate reassociation value with the type culture of A. fermentans $(65 \%)$ and low rates of 19,23 and $31 \%$, respectively, with the type cultures of A. schoenii, A. javanensis and strain UCD 67-278. DNA reassociation values between UCD 67-278 and the type cultures of A. schoenii, A. javanensis and A. fermentans did not exceed $30 \%$ (Supplementary Fig. S1).

Taken together, the results of sequence analysis, genetic hybridization and DNA-DNA reassociation strongly suggest that strain UCD 67-278 represents a novel species of the genus Arthroascus, while IFO 10138 represents a novel variety of the species $A$. fermentans.

\section{Arthroascus babjevae G. Naumov \& M. Th. Smith sp. nov.}

\section{Latin diagnosis of Arthroascus babjevae G. Naumov et M. Th. Smith sp. nov.}

In medio liquido post dies 3 cellulae ellipsoidae vel cylindricae $(2 \cdot 0-4 \cdot 0 \times 6 \cdot 0-35 \cdot 0 \mu \mathrm{m})$, singulae vel binae vel structurae 


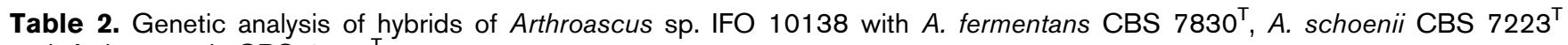
and $A$. javanensis $\mathrm{CBS} 2555^{\top}$

For hybrid 48, data for three independent hybrids are summarized. (1), (2) and (3) represent independently obtained hybrids.

\begin{tabular}{|c|c|c|c|c|c|}
\hline \multirow[t]{2}{*}{ Hybrid } & \multirow[t]{2}{*}{ Markers } & \multirow[t]{2}{*}{$\begin{array}{c}\text { Spores } \\
\text { isolated }(n)\end{array}$} & \multirow{2}{*}{$\begin{array}{c}\text { Proportion of } \\
\text { spores of hybrid } \\
\text { viable }(\%)\end{array}$} & \multirow{2}{*}{$\begin{array}{c}\begin{array}{c}\text { Ratio of } \\
\text { tetrads }^{*}\end{array} \\
\mathrm{P}: \mathrm{N}: \mathrm{T}:(+)\end{array}$} & \multirow{2}{*}{$\begin{array}{c}\begin{array}{c}\text { Segregation of } \\
\text { control markers } \dagger\end{array} \\
\mathrm{AB}: \mathrm{aB}: \mathrm{Ab}: \mathrm{ab}\end{array}$} \\
\hline & & & & & \\
\hline \multicolumn{6}{|c|}{ Arthroascus sp. IFO $10138 \times$ Arthroascus sp. IFO 10138} \\
\hline 46 & ade15 $\times$ leu 2 & 60 & 100 & $1: 1: 11: 0$ & $13: 13: 12: 13$ \\
\hline \multicolumn{6}{|c|}{ Arthroascus sp. IFO $10138 \times$ A. schoenii CBS $7223^{\mathrm{T}}$} \\
\hline \multirow[t]{2}{*}{49} & leu2 $\times$ lys4 (1) & 100 & 6 & - & $3: 0: 3: 0$ \\
\hline & leu2 $\times$ lys4 (2) & 15 & 0 & - & $(160: 0: 0: 0)$ \\
\hline \multicolumn{6}{|c|}{ Arthroascus sp. IFO $10138 \times A$. javanensis CBS $2555^{\mathrm{T}}$} \\
\hline 50 & leu $2 \times$ his 33 & 200 & 2 & - & $2: 0: 0: 0$ \\
\hline 51 & leu $2 \times \operatorname{thr} 10(1)$ & 100 & 1 & - & $1: 0: 0: 0$ \\
\hline 54 & ade15 $\times$ val11 & 100 & 0 & - & - \\
\hline \multicolumn{6}{|c|}{ Arthroascus sp. IFO $10138 \times A$. fermentans CBS $7830^{\mathrm{T}}$} \\
\hline & leu $2 \times \operatorname{ura15}(1)$ & 52 & 8 & - & $2: 0: 0: 0$ \\
\hline & leu $2 \times$ ura15 $(2)$ & 144 & 18 & $0: 0: 0: 2$ & $21: 0: 0: 0$ \\
\hline & leu $2 \times$ ura15 $(3)$ & 112 & 14 & $2: 0: 0: 2$ & $8: 4: 4: 0(61: 27: 11: 8)$ \\
\hline \multirow[t]{3}{*}{56} & leu $2 \times$ ade20 $(1)$ & 148 & 31 & $3: 0: 0: 3$ & $16: 10: 10: 0$ \\
\hline & leu $2 \times \operatorname{ade} 20(2)$ & 96 & 7 & $0: 0: 0: 1$ & $4: 0: 2: 0$ \\
\hline & leu $2 \times$ ade $20(3)$ & 352 & 12 & $1: 0: 0: 4$ & $23: 5: 12: 1$ \\
\hline \multirow[t]{3}{*}{57} & ade15 $\times$ ura15 $(1)$ & 52 & 6 & - & $2: 0: 0: 0$ \\
\hline & ade15 $\times$ ura $15(2)$ & 244 & 24 & $0: 1: 0: 5$ & $44: 3: 1: 6$ \\
\hline & ade15 $\times$ ura 15 & 176 & 10 & $2: 0: 0: 1$ & $8: 6: 4: 0(74: 39: 22: 8)$ \\
\hline
\end{tabular}

${ }^{\star} \mathrm{P}, \mathrm{N}, \mathrm{T}$ and $(+)$ represent respectively tetrads of parent ditype $(2 \mathrm{aB}: 2 \mathrm{Ab})$, non-parent ditype $(4 \mathrm{AB}: 0 \mathrm{ab})$, tetratype $(1 \mathrm{aB}: 1 \mathrm{Ab}: 1 \mathrm{AB}: 1 \mathrm{ab})$ and prototrophic tetrads $(4 \mathrm{AB})$. $\mathrm{a}$ and $\mathrm{b}$ are the auxotrophies of the first (before the crossing mark) and second parent, respectively. A and $\mathrm{B}$ are the prototrophies.

$\nmid$ Random spore analysis data obtained by micromanipulator are presented. The results of random spore analysis using diethyl ether treatment are given in parentheses.

pseudomycelii. Post 7 dies sedimentum adest. Species homothallica. Asci conjugati vel inconjugati, habentes 2-4 sporae. Asci deliquescentes. Ascosporae pustulatae, globosae vel oblatae cum annulum in (sub)equatorio. Fermentatio nulla. Glucosum, sucrosum, trehalosum, glycerolum, acidum succinicum et ethanolum assimilantur (lente). Non assimilantur galactosum, L-sorbosum, D-glucosaminum, D-ribosum, D-xylosum, L-arabinosum, D-arabinosum, L-rhamnosum, maltosum, methyl $\alpha$-glucosidum, cellobiosum, salicinum, arbutinum, melibiosum, lactosum, raffinosum, melizitosum, inulinum, amylum solubile, erythritolum, ribitolum, xylitolum, L-arabinitolum, D-glucitolum, D-mannitolum, galactitolum, inositolum, glucono- $\delta$-lactonum, acidum gluconicum, acidum glucuronicum, acidum DL-lacticum, acidum citricum, methanolum, lysinum, ethylaminum, cadaverinum, natrium nitricum et natrium nitrosum. Augmentum in $30^{\circ} \mathrm{C}$ at non in $35^{\circ} \mathrm{C}$. Ad crescentiam vitaminae externae necessariae sunt.
Crescit (lente) in medio addito $0 \cdot 01 \%$ cycloheximido. $\mathrm{G}+\mathrm{C}$ acidi deoxyribonucleati $30 \cdot 4 \mathrm{~mol} \%$.

Typus vivus et exsiccatus CBS $9167^{\mathrm{T}}$ (CBS H-18731) praeservatus in collectione Centraalbureau voor Schimmelcultures, Trajectum ad Rhenum.

\section{Description of Arthroascus babjevae G. Naumov \& M. Th. Smith sp. nov.}

Arthroascus babjevae [bab.je'vae. N.L. fem. gen. n. babjevae in honour of Dr I. P. Bab'eva (also transliterated as Babjeva), for her considerable contributions to yeast taxonomy and ecology].

In glucose/peptone/yeast extract (GPY) medium after 3 days, the cells are ellipsoidal to cylindrical $(2 \cdot 0-4 \cdot 0 \times 6 \cdot 0$ $35 \cdot 0 \mu \mathrm{m})$, single, in pairs or in pseudomycelial structures. 
Table 3. Genetic analysis of hybrids of Arthroascus sp. UCD 67-278 with A. fermentans CBS $7830^{\top}$, A. schoenii CBS $7223^{\top}$, A. javanensis CBS $2555^{\top}$ and Arthroascus sp. IFO 10138

For hybrids 60-65, data for several independent hybrids are summarized. (1), (2), (3) etc. indicate independently obtained hybrids.

\begin{tabular}{|c|c|c|c|c|}
\hline \multirow[t]{2}{*}{ Hybrid } & \multirow[t]{2}{*}{ Markers } & \multirow[t]{2}{*}{$\begin{array}{c}\text { Spores } \\
\text { isolated }(n)\end{array}$} & \multirow{2}{*}{$\begin{array}{c}\text { Proportion of } \\
\text { spores of hybrid } \\
\text { viable }(\%)\end{array}$} & \multirow{2}{*}{$\begin{array}{c}\begin{array}{c}\text { Segregation of } \\
\text { control markers }^{\star}\end{array} \\
\mathrm{AB}: \mathrm{aB}: \mathrm{Ab}: \mathrm{ab}\end{array}$} \\
\hline & & & & \\
\hline \multicolumn{5}{|c|}{ Arthroascus sp. UCD 67-278 $\times$ Arthroascus sp. UCD 67-278 } \\
\hline 58 & lys $1 \times \arg 5$ & 208 & 82 & $36: 25: 24: 31 \dagger$ \\
\hline 59 & $\operatorname{lys} 1 \times \arg 3$ & 104 & 84 & $14: 14: 14: 14 \dagger$ \\
\hline \multicolumn{5}{|c|}{ Arthroascus sp. UCD $67-278 \times A$. fermentans CBS $7830^{\mathrm{T}}$} \\
\hline \multirow[t]{2}{*}{60} & lys1 $\times \operatorname{ura15}(1)$ & 244 & 5 & $7: 3: 2: 0$ \\
\hline & lys $1 \times$ ura15 $(2)$ & - & - & $(88: 103: 0: 0)$ \\
\hline \multirow[t]{2}{*}{61} & $\arg 5 \times \operatorname{ade} 20(1)$ & 302 & 8 & $19: 4: 2: 0$ \\
\hline & $\arg 5 \times \operatorname{ade} 20(2)$ & - & - & $(78: 94: 0: 0)$ \\
\hline 62 & $\arg 3 \times \operatorname{ade} 20(1-6)$ & 269 & 1 & $3: 1: 0: 0(118: 0: 0: 0)$ \\
\hline \multicolumn{5}{|c|}{ Arthroascus sp. UCD $67-278 \times$ A. schoenii CBS $7223^{\mathrm{T}}$} \\
\hline 63 & lys $1 \times$ ade12 $(1,2)$ & 116 & 0 & $(180: 0: 0: 0)$ \\
\hline 64 & $\arg 3 \times \operatorname{lys} 4(1,2)$ & 112 & 2 & $5: 0: 0: 0(96: 0: 0: 0)$ \\
\hline \multicolumn{5}{|c|}{ Arthroascus sp. UCD 67-278 $\times$ A. javanensis CBS $2555^{\mathrm{T}}$} \\
\hline 65 & lys1 $\times \operatorname{thr10}(1,2)$ & 112 & 0 & $(106: 0: 0: 0)$ \\
\hline 66 & $\arg 3 \times \operatorname{his} 33(1,2)$ & 112 & 0 & $(167: 0: 11: 0)$ \\
\hline \multicolumn{5}{|c|}{ Arthroascus sp. UCD 67-278 $\times$ Arthroascus sp. IFO 10138} \\
\hline \multirow[t]{2}{*}{67} & lys $1 \times$ ade15 $(1,2)$ & 116 & 2 & $0: 0: 2: 0(65: 1: 29: 0)$ \\
\hline & lys $1 \times$ ade15 $(3)$ & 40 & 0 & $(67: 115: 0: 0)$ \\
\hline 68 & $\arg 3 \times \operatorname{leu} 2(1-3)$ & 152 & 1 & $0: 2: 0: 0(23: 60: 0: 0)$ \\
\hline
\end{tabular}

${ }^{*} \mathrm{a}$ and $\mathrm{b}$ are the auxotrophies of the first (before the crossing mark) and second parent, respectively. A and $\mathrm{B}$ are the prototrophies. Random spore analysis data obtained by micromanipulator are presented. The results of random spore analysis using diethyl ether treatment are given in parentheses.

$\dagger$ Ratio of tetrads $\mathrm{P}: \mathrm{N}: \mathrm{T}$ in hybridizations 58 and 59 were $0: 5: 14$ and $1: 1: 9$, respectively, where $\mathrm{P}, \mathrm{N}$ and $\mathrm{T}$ are the tetrads of parent ditype $(2 \mathrm{aB}: 2 \mathrm{Ab})$, non-parent ditype $(4 \mathrm{AB}: 0 \mathrm{ab})$ and tetratype $(1 \mathrm{aB}: 1 \mathrm{Ab}: 1 \mathrm{AB}: 1 \mathrm{ab})$, respectively.

After 1 week, sediment and an incomplete tiny ring are present. On Dalmau plate cultures on GPY agar, a welldeveloped pseudomycelium and septate mycelium is formed. Blastoconidia are not produced. Asci are formed directly from single cells or following conjugation between independent cells. Asci become deliquescent at maturity. Each ascus forms two to four warty ascospores that are globose to oblate with a narrow (sub)equatorial ledge (Fig. 4). Ascosporulation after 3 days on $5 \%$ Difco malt, V8 and GPY agars. Fermentation is absent. Glucose, sucrose, trehalose, glycerol, succinic acid and ethanol are assimilated (slowly). Growth does not occur on galactose, L-sorbose, D-glucosamine, D-ribose, D-xylose, L-arabinose, D-arabinose, L-rhamnose, maltose, methyl $\alpha$-glucoside, cellobiose, salicin, arbutin, melibiose, lactose, raffinose, melezitose, inulin, starch, erythritol, ribitol, xylitol, L-arabinitol, D-glucitol, D-mannitol, galactitol, inositol, glucono- $\delta$-lactone, D-gluconate, D-glucuronate, DL-lactate, citrate, methanol, nitrite, nitrate, lysine, ethylamine or cadaverine. Growth occurs at

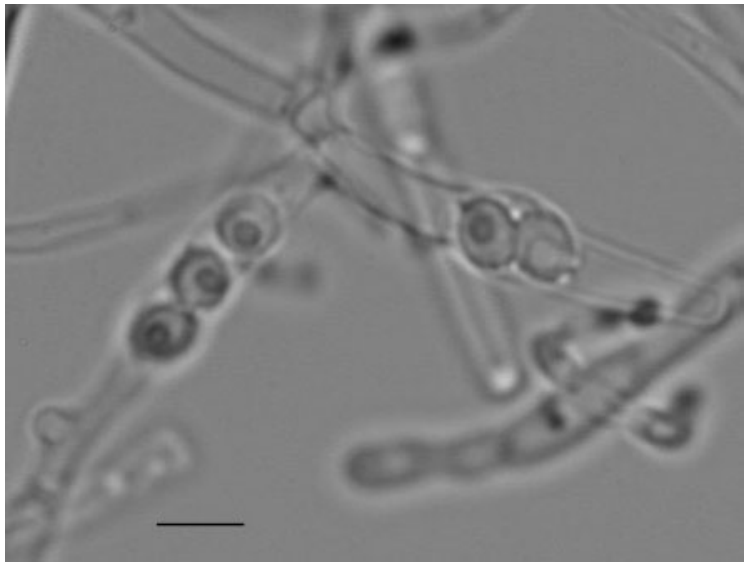

Fig. 4. Asci with ascospores of Arthroascus babjevae sp. nov. UCD $67-278^{\top}$. Ascosporulation occurred after 7 days on Difco malt agar at $25^{\circ} \mathrm{C}$. Bar, $5 \mu \mathrm{m}$. 
$30{ }^{\circ} \mathrm{C}$ and in $0.01 \%$ cycloheximide (slowly); growth does not occur at $35^{\circ} \mathrm{C}$ or in medium without vitamins. DNA $\mathrm{G}+\mathrm{C}$ content is $30 \cdot 4 \mathrm{~mol} \%$.

The type strain, UCD $67-278^{\mathrm{T}}\left(=\mathrm{CBS} 9167^{\mathrm{T}}\right)$ (dried CBS H-18731, holotype), has been deposited in the Centraalbureau voor Schimmelcultures, Utrecht, The Netherlands.

\section{Ila. Arthroascus fermentans C.-F. Lee, F.-L. Lee, Hsu \& Phaff var. fermentans}

Int J Syst Bacteriol (1994) 44, 305.

Synonym: Saccharomycopsis fermentans (C.-F. Lee, F.-L. Lee, Hsu \& Phaff) Kurtzman \& Robnett, Can J Bot (1995) 73, S829.

Ex-type strain: CBS 7830 (ex-holotype), isolated from soil of a papaya orchard, Taiwan.

\section{Ilb. Arthroascus fermentans var. arxii G. Naumov \& M. Th. Smith var. nov.}

Arthroascus fermentans var. arxii (ar'xi.i. N.L. masc. gen. $\mathrm{n}$. arxii in honour of Dr J. A. von Arx, who introduced the genus Arthroascus in 1972).

Varietas Arthroascus fermentans var. arxii differt: sucrosum assimilatur. Typus vivus et exsiccatus CBS $9168^{\mathrm{T}}$ (CBS $\mathrm{H}-18732$ ) praeservatus in collectione Centraalbureau voor Schimmelcultures, Trajectum ad Rhenum.

Arthroascus fermentans var. arxii differs from variety fermentans by the presence of growth on sucrose. The type strain, IFO $10138^{\mathrm{T}}\left(=\mathrm{CBS} 9168^{\mathrm{T}}\right)$ (dried CBS H-18732, holotype), isolated from a flower of Tricyrtis flava in Japan, has been deposited in the Centraalbureau voor Schimmelcultures, Utrecht, The Netherlands.

\section{Arthroascus javanensis (Klöcker) von Arx}

Antonie van Leeuwenhoek (1972) 38, 306.

Basionym: Endomyces javanensis Klöcker, C R Trav Lab Carlsberg (1909) 7, 267.

Synonyms: Schwanniomyces javanensis (Klöcker) Zender, Bull Soc Bot Geneve (1926) 17, 208; Endomycopsis javanensis (Klöcker) Dekker (in Stelling-Dekker, Die Sporogenen Hefen, Verh K Ned Akad Wetensch Afd Natuurk Sect II, 265, 1931); Schizosaccharomyces javanensis (Klöcker) Streiblová, Folia Microbiol (1963) 8, 174; Saccharomycopsis javanensis (Klöcker) Kurtzman \& Robnett, Can J Bot (1995) 73, S829.

Type strain: CBS 2555 (ex-holotype), isolated from soil, Java, Indonesia, and described by Klöcker (1909), was sent to the CBS Yeast collection by Guilliermond.

\section{Arthroascus schoenii (Nadson \& Krassilnikov) Babjeva, Vustin, Naumov \& Vinovarova}

Mikrobiologiia (1985) 54, 727.

Synonyms: Endomyces schoenii Nadson \& Krassilnikov, Dokl Akad Nauk SSSR (1932) 13, 313; Saccharomycopsis schoenii (Nadson \& Krassilnikov) Kurtzman \& Robnett, Can J Bot (1995) 73, S829; Pichia nonfermentans Nakase, J Gen Appl Microbiol (1971) 17, 469.

Type strain: CBS 7223 (ex-holotype), isolated from exudates of oak (Quercus sp.).

\section{Key to the species}

1. a. Glucose fermented 2

b. Glucose not fermented 3

2. a. Sucrose assimilated (slowly)

Arthroascus fermentans var. arxii

b. Sucrose not assimilated Arthroascus fermentans var. fermentans

3. a. L-Sorbose assimilated 4

b. L-Sorbose not assimilated Arthroascus babjevae

4. a. N-Acetyl-D-glucosamine Arthroascus javanensis assimilated

b. N-Acetyl-D-glucosamine Arthroascus schoenii not assimilated

\section{ACKNOWLEDGEMENTS}

The authors would like to thank V. I. Kondratieva and N. G. Tokareva for help in the genetic part of this study. G. I. N. and E. S. N. are grateful to A. M. ten Berge for kind attention during their stay in the Netherlands and to the Centraalbureau voor Schimmelcultures (Utrecht) for the invitation to work as visiting scientists. Strains of A. schoenii were kindly supplied by H. J. Phaff, K. Boundy-Mills, C. P. Kurtzman and M.-A. Lachance. Gé Poot is acknowledged for his technical assistance.

\section{REFERENCES}

Bab'eva, I. P., Vustin, M. M., Naumov, G. I. \& Vinovarova, M. E. (1986). Arthroascus schoenii nov. comb., a yeast-like organism. Microbiology (English translation of Mikrobiologiia) 54, 575-580.

Bowles, J. M. \& Lachance, M.-A. (1983). Patterns of variation in the yeast florae of exudates in an oak community. Can J Bot 61, 2984-2995.

Dawes, I. W. \& Hardie, I. D. (1974). Selective killing of vegetative cells in sporulated yeast cultures by exposure to diethyl ether. Mol Gen Genet 131, 281-289.

Gerrits van den Ende, A. H. G. \& de Hoog, G. S. (1999). Variability and molecular diagnostics of the neurotropic species Cladophialophora bantiana. Stud Mycol 43, 151-162. 
Klöcker, A. (1909). Endomyces javanensis nov. sp. C R Trav Lab Carlsberg 7, 267-272.

Kreger-van Rij, N. J. W. (1970). Endomycopsis. In The Yeasts, a Taxonomic Study, 2nd edn, pp. 166-208. Edited by J. Lodder. Amsterdam: North-Holland.

Kreger-van Rij, N. J. W. (1984a). Genus 2. Arthroascus von Arx. In The Yeasts, a Taxonomic Study, 3rd edn, pp. 114-116. Edited by N. J. W. Kreger-van Rij. Amsterdam: Elsevier.

Kreger-van Rij, N. J. W. (1984b). Genus 24. Saccharomycopsis Schionning. In The Yeasts, a Taxonomic Study, 3rd edn, pp. 399-413. Edited by N. J. W. Kreger-van Rij. Amsterdam: Elsevier.

Kreger-van Rij, N. J. W. \& Veenhuis, M. (1973). Electron microscopy of some special cell contacts in yeasts. J Bacteriol 113, 350-356.

Kurtzman, C. P. (1999). Two new members of the Saccharomycopsis clade: Saccharomycopsis microspora, comb. nov. and Candida lassenensis, sp. nov. Mycotaxon 71, 241-250.

Kurtzman, C. P. \& Robnett, C. J. (1995). Molecular relationships among hyphal ascomycetous yeasts and yeastlike taxa. Can J Bot 73, S824-S830.

Kurtzman, C. P. \& Robnett, C. J. (1997). Identification of clinically important ascomycetous yeasts based on nucleotide divergence of the $5^{\prime}$ end of the large subunit (26S) ribosomal DNA gene. J Clin Microbiol 35, 1216-1223.

Kurtzman, C. P. \& Robnett, C. J. (1998). Identification and phylogeny of ascomycetous yeasts from analysis of nuclear large subunit (26S) ribosomal DNA partial sequences. Antonie van Leeuwenhoek 73, 331-371.

Kurtzman, C. P. \& Smith, M. Th. (1998). Saccharomycopsis Schiönning. In The Yeasts, a Taxonomic Study, 4th edn, pp. 374-386. Edited by C. P. Kurtzman \& J. W. Fell. Amsterdam: Elsevier.

Lachance, M.-A. (1995). Yeast communities in a natural tequila fermentation. Antonie van Leeuwenhoek 68, 151-160.

Lachance, M.-A. \& Bowles, J. M. (2002). Metschnikowia arizonensis and Metschnikowia dekortorum, two new large-spored yeast species associated with floricolous beetles. FEMS Yeast Res 2, 81-86.

Lachance, M.-A. \& Bowles, J. M. (2004). Metschinikowia similis sp. nov. and Metschnikowia colocasiae sp. nov., two ascomycetous yeasts isolated from Conotelus spp. (Coleoptera: Nitidulidae) in Costa Rica. Stud Mycol 50, 69-76.

Lachance, M.-A., Pupovac-Velikonja, A., Natarajan, S. \& SchlagEdler, B. (2000). Nutrition and phylogeny of predacious yeasts. Can J Microbiol 46, 495-505.

Lee, C.-F., Lee, F.-L., Hsu, W.-H. \& Phaff, H. J. (1994). Arthroascus fermentans, a new yeast species isolated from soil in Taiwan. Int J Syst Bacteriol 44, 303-307.

Liti, G., Peruffo, A., James, S. A., Roberts, I. N. \& Louis, E. J. (2005). Inferences of evolutionary relationships from a population survey of LTR-retrotransposons and telomeric-associated sequences in the Saccharomyces sensu stricto complex. Yeast 22, 177-192.

Lodder, J. \& Kreger-van Rij, N. J. W. (editors) (1952). The Yeasts a Taxonomic Study. Amsterdam: North-Holland.

Mikata, K. (1985). Descriptive catalogue of IFO yeast collection. V. 30. Arthroascus javanensis (Klöcker) von Arx. IFO Res Commun 12, 112-113.

Nadson, G. A. \& Krassilnikov, N. A. (1932). Recherches sur la structure, le dévelopement et la formation des races stables chez les Endomycétacées. C R Acad Sci URSS 13, 313-332 (in Russian with French summary).

Nakase, T. (1971). Four new yeasts found in Japan. J Gen Appl Microbiol 17, 469-478.
Naumov, G. I. (1987). Results of the genosystematics of the yeast Williopsis Zender and Zygowilliopsis Kudriavzev. Mol Genet Mikrobiol Virusol 2, 1-7 (in Russian).

Naumov, G. I. (1996). Genetic identification of biological species in the Saccharomyces sensu stricto complex. J Ind Microbiol 17, 295-302.

Naumov, G. I. \& Naumova, E. S. (2002). Five new combinations in the yeast genus Zygofabospora Kudriavzev emend. G. Naumov (pro parte Kluyveromyces) based on genetic data. FEMS Yeast Res 2, 39-46.

Naumov, G. I., Vustin, M. M. \& Babjeva, I. P. (1985). Genetic identification of two species of yeast-like fungi in the genus Arthroascus von Arx. Dokl Biol Sci (English translation of Dokl Akad Nauk) 281, 211-213.

Naumov, G., Naumova, E., Azbukina, Z. M., Korhola, M. \& Gaillardin, C. (1993). Genetic and karyotypic identification of Saccharomyces yeasts from Far East Asia. Cryptogam Mycol 14, 85-93.

Naumov, G. I., Naumova, E. S., Kondratieva, V. I., Bulat, S. A., Mironenko, N. V., Mendonça-Hagler, L. C. \& Hagler, A. N. (1997a). Genetic and molecular delineation of three sibling species in the Hansenula polymorpha complex. Syst Appl Microbiol 20, 50-56.

Naumov, G. I., Naumova, E. S. \& Sniegowski, P. D. (1997b). Differentiation of European and Far East Asian populations of Saccharomyces paradoxus by allozyme analysis. Int J Syst Bacteriol 47, 341-344.

Naumov, G. I., Naumova, E. S. \& Sniegowski, P. D. (1998). Saccharomyces paradoxus and Saccharomyces cerevisiae are associated with exudates of North American oaks. Can J Microbiol 44, 1045-1050.

Naumov, G. I., James, S. A., Naumova, E. S., Louis, E. J. \& Roberts, I. N. (2000). Three new species in the Saccharomyces sensu stricto complex: Saccharomyces cariocanus, Saccharomyces kudriavzevii and Saccharomyces mikatae. Int J Syst Evol Microbiol 50, 1931-1942.

Naumov, G. I., Naumova, E. S., Smith, M. T. \& de Hoog, G. S. (2003). Ribosomal DNA sequencing and reinstatement of the genus Arthroascus von Arx. J Gen Appl Microbiol 49, 267-270.

Naumova, E. S., Sukhotina, N. N. \& Naumov, G. I. (2004). Molecular-genetic differentiation of the dairy yeast Kluyveromyces lactis and its closest wild relatives. FEMS Yeast Res 5, 263-269.

Phaff, H. J. \& Knapp, E. P. (1956). The taxonomy of yeasts found in exudates of certain trees and other natural breeding sites of some species of Drosophila. Antonie van Leeuwenhoek 22, 117-130.

Phaff, H. J., Miller, M. W., Yoneyama, M. \& Soneda, M. (1972). A comparative study of the yeast florae associated with trees on the Japanese islands and on the west coast of North America. In Fermentation Technology Today, pp. 759-774. Edited by G. Terui. Osaka: Society of Fermentation Technology.

Pimenta, R. S., Silva, F. L., Corrêa, A. \& Rosa, C. A. (2004). Biological control of Penicillium italicum and P. expansum by the predacious yeast Saccharomycopsis javanensis on oranges. In Congress Book. Eleventh International Congress on Yeasts (ICY2004), p. 77. Rio de Janeiro, Brazil, 15-20 August 2004.

Pitt, J. I. \& Miller, M. W. (1970). Speciation in the yeast genus Metschnikowia. Antonie van Leeuwenhoek 36, 357-381.

Smith, M. Th., Poot, G. A. \& Batenburg-van der Vegte, W. H. (1990). Genome comparison among species of the genus Arthroascus von Arx. Antonie van Leeuwenhoek 58, 249-253.

Smith, M. Th., de Cock, A. W. M., Poot, G. A. \& Steensma, H. Y. (1995). Genome comparison in the yeastlike fungal genus Galactomyces Redhead et Malloch. Int J Syst Bacteriol 45, 826-831.

Stelling-Dekker, N. M. (1931). Die Sporogen Hefen Teil 1. Verh K Ned Akad Wetenschap Afd Natuurk Sect II 28, 1-547 (in Dutch).

Van de Peer, Y. \& De Wachter, R. (1994). TREECON for Windows: a software package for the construction and drawing of evolutionary trees for the Microsoft Windows environment. Comput Appl Biosci 10, 569-570. 
von Arx, J. A. (1972). On Endomyces, Endomycopsis and related yeastlike fungi. Antonie van Leeuwenhoek 38, 289-309.

Yamada, Y., Higashi, T. \& Mikata, K. (1998). The phylogeny of species of the ascogenous teleomorphic yeast genera Ambrosiozyma, Hormoascus, Hyphopichia, Arthroascus, and Botryoascus based on the partial sequences of $18 \mathrm{~S}$ and $26 \mathrm{~S}$ ribosomal RNAs. Bull Fac Agric Shizuoka Univ 48, 1-13.

Yarrow, D. (1998). Methods for the isolation, maintenance and identification of yeasts. In The Yeasts, a Taxonomic Study, 4th edn, pp. 77-100. Edited by C. P. Kurtzman \& J. W. Fell. Amsterdam: Elsevier. 